\title{
DETERMINAN TRANSAKSI NONTUNAI DI INDONESIA DENGAN PENDEKATAN ERROR CORRECTION MECHANISM (ECM) MODEL*
}

\author{
Zulfa Nur Fajri Ramadhani $i^{1 \ddagger}$ and Siskarossa Ika Oktora ${ }^{2}$ \\ ${ }^{1}$ Politeknik Statistika STIS, Indonesia, zulfanurfaji@gmail.com \\ 2Politeknik Statistika STIS, Indonesia, siskarossa@stis.ac.id \\ Fcorresponding author
}

Indonesian Journal of Statistics and Its Applications (eISSN:2599-0802)

Vol 3 No 1 (2019), 62 - 77

Copyright @ 2019 Zulfa Nur Fajri Ramadhani and Siskarossa Ika Oktora. This is an open-access article distributed under the Creative Commons Attribution License, which permits unrestricted use, distribution, and reproduction in any medium, provided the original work is properly cited.

\begin{abstract}
Consumption is an activity that must be done by everyone. In order to consume something, a transaction is needed to get the goods or services desired. One kind of transaction that is used by many people nowadays is non-cash transaction. Since Bank Indonesia established Gerakan Nasional Non Tunai (GNNT) in August 2014, the value of non-cash transactions exceeds the value of cash transactions. It happenned because people prefer non-cash to cash transaction which is easier, safer, more practical, and more economical. Besides, an increase in non-cash transactions can also be influenced by other factors. Therefore, a study is conducted to analyze the determinants of noncash transactions from the macro side by using Error Correction Mechanism (ECM). The data used in this study are secondary data from Bank Indonesia and Badan Pusat Statistik with monthly period from January 2010 until December 2017. The results showed that in the long run, private savings and $\mathrm{BI}$ rate have positive effect on non-cash transactions. In the short run, private savings and money supply have positive effect on non-cash transactions. While inflation does not affect non-cash transactions, both in the short and long run.
\end{abstract}

Keywords: consumption, ECM, non-cash transactions.

\section{Pendahuluan}

Setiap negara, termasuk Indonesia, selalu berusaha untuk meningkatkan pertumbuhan ekonominya dengan melakukan pembangunan di segala sektor, seperti infrastruktur, pendidikan, dan kesehatan. Hal ini dilakukan untuk menjamin

\footnotetext{
*Received Nov 2018; Accepted Des 2018; Published online on Feb 2019
} 
kesejahteraan rakyat di negara tersebut. Kesejahteraan yang terjamin tentu akan mendorong terciptanya keharmonisan dalam kehidupan bermasyarakat sehingga dapat mengurangi beban pemerintah karena tidak akan lagi timbul masalah ekonomi dan sosial seperti kemiskinan, ketimpangan, kriminalitas, dan lain lain.

Persaulian et al. (2013) menyatakan bahwa salah satu komponen penting untuk menilai perkembangan tingkat kesejahteraan ekonomi penduduk adalah pola pengeluaran konsumsi masyarakat. Pengeluaran konsumsi masyarakat merupakan belanja yang dilakukan rumah tangga terhadap barang dan jasa akhir yang digunakan untuk memenuhi kebutuhannya. Kebutuhan atas barang dan jasa tersebut antara lain, seperti makanan, minuman, pakaian, alas kaki, perumahan, kesehatan, pendidikan, transportasi, komunikasi, restoran, hotel, serta barang dan jasa lainnya. Pengeluaran konsumsi masyarakat di suatu negara merupakan total pengeluaran konsumsi semua orang di negara yang bersangkutan.

Keputusan konsumsi rumah tangga juga dapat memengaruhi keseluruhan perilaku perekonomian, baik dalam jangka panjang maupun jangka pendek. Kontribusi konsumsi yang besar tentu akan sangat berpengaruh terhadap perekonomian suatu negara jika terjadi perubahan terhadap konsumsi masyarakat. Berdasarkan data Badan Pusat Statistik (2017), kontribusi pengeluaran konsumsi rumah tangga sebesar 56,13 persen dari total Produk Domestik Bruto (PDB) Indonesia yang berarti konsumsi rumah tangga memiliki dampak besar terhadap perekonomian Indonesia.

Salah satu hal yang dapat dilihat dari pola konsumsi rumah tangga adalah daya beli masyarakat. Pertumbuhan konsumsi rumah tangga (year on year) pada 2014 hingga 2017 cenderung melambat meskipun perlambatannya hanya sebesar 0 sampai 0,1 persen. Pada triwulan pertama tahun 2014, pengeluaran konsumi rumah tangga tumbuh sebesar 5,23 persen dan terus mengalami perlambatan hingga di bawah lima persen. Pertumbuhan sempat naik menjadi 5,07 persen pada triwulan kedua tahun 2016, tetapi kembali melambat di periode selanjutnya. Hal ini menggambarkan adanya perubahan daya beli masyarakat, yaitu kecenderungan masyarakat untuk menahan konsumsi dan mengalokasikan pendapatannya untuk kegiatan lain.

Marta (2017) berpendapat bahwa perubahan daya beli masyarakat terjadi karena adanya pergeseran pola belanja masyarakat dari perdagangan konvensional ke perdagangan elektronik. Semakin kompleksnya kegiatan perekonomian masyarakat menuntut tersedianya sarana yang dapat memfasilitasi lalu lintas pertukaran barang dan jasa tersebut. Peran teknologi sangat diperlukan agar transaksi dapat dilakukan secara efisien tanpa harus mengeluarkan biaya yang besar. Perkembangan teknologi ini menghasilkan suatu sistem penjualan yang dilakukan dalam jaringan (daring) atau sering disebut e-commerce. Transaksi daring ini sudah banyak digunakan masyarakat, namun menurut BPS dalam Embu (2017), saat ini belum tersedia data e-commerce yang lengkap sehingga tidak ada data akurat mengenai total belanja daring. Hal inilah yang menjadi salah satu penyebab menurunnya data pengeluaran konsumsi rumah tangga.

Saat ini, uang tunai masih berperan penting dalam kegiatan transaksi yang dilakukan masyarakat. Adanya bentuk fisik dari uang yang dapat dibelanjakan membuat kegiatan transaksi yang dilakukan menjadi lebih nyata. Namun, perkembangan teknologi mengubah pola konsumsi masyarakat ke arah yang lebih modern dan diikuti dengan perkembangan sistem transaksi dari tunai menjadi nontunai. Kedua jenis transaksi ini dapat digunakan secara bersamaan maupun bergantian, sesuai dengan preferensi pemakainya. Uang tunai dapat berperan sebagai substitusi yang menggantikan nontunai atau sebagai komplementer yang melengkapi 
nontunai. Semakin banyak konsumsi yang dilakukan masyarakat, semakin banyak pula transaksi yang dilakukan.

Semakin meningkatnya transaksi yang dilakukan masyarakat menjadi salah satu penyebab semakin berkembangnya sistem pembayaran nontunai. Selain itu, adanya Gerakan Nasional Nontunai (GNNT) yang dicanangkan Bank Indonesia (BI) sejak 14 Agustus 2014 juga turut berperan dalam peningkatan transaksi nontunai yang dilakukan masyarakat. Program ini bertujuan untuk menciptakan less cash society dan meminimalisasi penggunaan uang tunai dengan meningkatkan penggunaan nontunai. Transaksi nontunai ini nantinya dapat mendorong perekonomian melalui konsumsi masyarakat karena semakin mudahnya kegiatan jual beli barang kebutuhan masyarakat.

Program GNNT ini berdampak positif terhadap penggunaan nontunai di Indonesia. Sejak adanya GNNT, masyarakat Indonesia melakukan lebih banyak transaksi nontunai dibandingkan transaksi tunai. Nilai transaksi nontunai yang lebih besar ini dimulai sejak September 2014, yaitu sebesar 401,45 triliun rupiah sedangkan transaksi tunai sebesar 395,23 triliun rupiah. Hal ini terus berlanjut hingga Desember 2017 yang menandakan adanya kecenderungan masyarakat untuk mulai beralih dari transaksi tunai ke nontunai.

Kartu kredit, kartu ATM/debet, dan uang elektronik merupakan alat pembayaran nontunai yang paling sering digunakan masyarakat. Fungsi dari alat pembayaran tersebut sama dengan uang tunai dan meskipun sumber dana untuk ketiga alat pembayaran tersebut berbeda, tetapi tujuan dari penggunaannya sama, yaitu untuk berbelanja, mengirim uang, membayar berbagai tagihan, dan lain-lain. Alat pembayaran nontunai ini sangat memudahkan masyarakat dalam bertransaksi sehingga perputaran uang menjadi sangat cepat. Kemudahan yang ditawarkan transaksi nontunai mendorong masyarakat untuk berperilaku konsumtif, yaitu sering melakukan pembelian secara tidak terencana. Hal ini dapat disebabkan oleh tingginya tingkat tabungan yang dimiliki sehingga banyak uang yang dialokasikan untuk melakukan konsumsi. Tabungan dijadikan sebagai dana untuk melakukan konsumsi sehingga semakin tinggi tabungan yang dimiliki, kecenderungan untuk melakukan konsumsi barang dan jasa akan semakin tinggi pula. Konsumsi yang meningkat ini nantinya akan meningkatkan transaksi nontunai yang dilakukan masyarakat.

Konsumsi yang terus meningkat pada periode tertentu dapat menyebabkan peningkatan permintaan barang dan jasa untuk konsumsi masyarakat yang tidak diikuti dengan penawarannya. Hal ini akan meningkatkan harga barang dan jasa sehingga memicu terjadinya inflasi. Jika inflasi terjadi tentu akan mengurangi konsumsi masyarakat karena masyarakat lebih memilih barang dan jasa yang lebih murah atau menyimpan uangnya di bank dan mendapatkan bunga dari bank (Putera, 2017). Dengan begitu, semakin tinggi inflasi dan suku bunga, konsumsi masyarakat akan semakin menurun karena masyarakat tidak ingin menggunakan uangnya untuk belanja barang yang mahal dan memilih menyimpan uang di bank untuk mendapatkan banyak bunga sehingga penggunaan nontunai juga semakin sedikit.

Guariglia dan Loke (2004) melakukan penelitian untuk mengetahui determinan nilai dan volume transaksi nontunai pada negara-negara Eropa dan Amerika Utara. Hasil penelitian menunjukkan bahwa faktor kebiasaan dan teknologi berpengaruh positif terhadap nilai dan volume transaksi nontunai, suku bunga berpengaruh positif terhadap nilai transaksi nontunai tetapi tidak berpengaruh terhadap volumenya, sedangkan jumlah uang beredar berpengaruh positif terhadap nilai transaksi nontunai tetapi berpengaruh negatif terhadap volumenya. Selain itu, Astuti (2017) melakukan penelitian tentang analisis determinan permintaan uang elektronik di Indonesia dengan 
hasil bahwa secara umum, jumlah uang beredar, pendapatan per kapita, dan kecepatan perputaran uang berpengaruh terhadap permintaan uang elektronik di Indonesia.

Transaksi nontunai digunakan sebagai sarana untuk melakukan konsumsi sehingga faktor-faktor yang memengaruhi konsumsi juga dapat memengaruhi transaksi nontunai. Penelitian Ragandhi (2011) menunjukkan bahwa dalam jangka panjang pendapatan nasional dan inflasi berpegaruh positif terhadap konsumsi masyarakat, sedangkan suku bunga deposito berpengaruh negatif. Dalam jangka pendek, pendapatan nasional, inflasi, dan suku bunga deposito tidak berpengaruh terhadap konsumsi masyarakat. Selanjutnya, pada penelitian Meilani (2016) didapatkan hasil bahwa dalam jangka pendek, pendapatan nasional berpengaruh positif terhadap konsumsi masyarakat. Dalam jangka panjang, jumlah uang beredar, suku bunga, pendapatan nasional berpengaruh positif terhadap konsumsi masyarakat. Sedangkan inflasi tidak berpengaruh, baik di jangka pendek maupun jangka panjang.

Semakin meningkatnya transaksi nontunai yang dilakukan masyarakat dari waktu ke waktu menjadi suatu alasan pentingnya dilakukan penelitian mengenai determinan transaksi nontunai di Indonesia. Penelitian ini bertujuan untuk menggambarkan secara umum mengenai transaksi nontunai, tabungan masyarakat, jumlah uang beredar (M1), inflasi, dan suku bunga di Indonesia pada periode 2010 hingga 2017 serta menganalisis hubungan dan pengaruh variabel-variabel tersebut dengan menggunakan metode Error Correction Mechanism (ECM).

\section{Metodologi}

Penelitian ini dilakukan untuk menganalisis pengaruh jangka pendek dan jangka panjang antara tabungan masyarakat, jumlah uang beredar (M1), inflasi, dan BI rate terhadap transaksi nontunai. Transaksi nontunai dijadikan sebagai variabel dependen dan merupakan total dari transaksi kartu kredit, kartu ATM/debet, dan uang elektronik. Sedangkan tabungan masyarakat, jumlah uang beredar (M1), inflasi, dan BI rate dijadikan sebagai variabel independen.

\subsection{Bahan dan Data}

Data yang digunakan dalam penelitian ini merupakan data sekunder yang bersumber dari publikasi bulanan Bank Indonesia (BI) dan Badan Pusat Statistik (BPS) dalam rentang waktu Januari 2010 hingga Desember 2017 berupa data deret waktu dengan jumlah observasi sebanyak 96 unit. Data nilai transaksi kartu kredit, kartu ATM/debet, dan uang elektronik diperoleh dari publikasi Statistik Sistem Pembayaran (SSP) yang dikeluarkan BI. Data tabungan masyarakat, jumlah uang beredar (M1), dan BI rate diperoleh dari publikasi Statistik Ekonomi dan Keuangan Indonesia (SEKI) yang dikeluarkan BI. Sedangkan data inflasi diperoleh dari publikasi BPS.

\subsection{Metode Penelitian}

Dalam penelitian ini, digunakan analisis deskriptif dan inferensia untuk menjawab tujuan penelitian. Analisis deskriptif disajikan melalui grafik untuk memberikan gambaran umum mengenai pekembangan transaksi nontunai, tabungan masyarakat, jumlah uang beredar (M1), inflasi, dan BI rate di Indonesia selama periode penelitian, yaitu 2010 hingga 2017. Analisis inferensia digunakan untuk menganalisis pengaruh jangka pendek dan jangka panjang antara tabungan masyarakat, jumlah uang beredar (M1), inflasi, dan BI rate terhadap transaksi nontunai dengan metode Error Correction Mechanism (ECM). Transaksi nontunai dijadikan variabel independen, sedangkan variabel-variabel lainnya dijadikan variabel dependen. Adapun tahapan estimasi menggunakan ECM adalah sebagai berikut: 


\section{Uji Stasioneritas}

Stasioneritas merupakan hal penting yang harus diperhatikan dalam melakukan estimasi data deret waktu. Data yang tidak stasioner akan menimbulkan masalah autokorelasi dan adanya regresi lancung (spurious regression) yang ditandai dengan tingginya nilai koefisien determinasi $\left(R^{2}\right)$ meskipun tidak terdapat hubungan antara variabel dependen dan independen (Gujarati, 2004). Menurut Widarjono (2005), data deret waktu dikatakan stasioner jika memenuhi tiga kriteria, yaitu ratarata dan variannya konstan sepanjang waktu serta kovarian yang tidak saling berkorelasi antarwaktu.

Syarat untuk menggunakan ECM adalah semua variabel yang digunakan dalam model stasioner pada orde yang sama $(I(d))$. Sebelumnya melakukan pengujian stasioneritas, variabel transaksi nontunai, tabungan masyarakat, dan jumlah uang beredar (M1) ditransformasi ke dalam bentuk pertumbuhan (year on year) terlebih dahulu. Misalkan yang ditransformasi menjadi pertumbuhan adalah variabel transaksi nontunai, maka:

Keterangan:

$$
\text { YOYNONTUNAI } I_{m, y}=\frac{N O N T U N A I_{m, y}-N O N T U N A I_{m, y-1}}{N O N T U N A I_{m, y-1}} \times 100
$$

YOYNONTUNAI : pertumbuhan (year on year) variabel nontunai

$\mathrm{m} \quad$ : data pada bulan ke-m, $\mathrm{m}=1,2, \ldots, 12$

y : data pada tahun ke-y, $y=2010,2011, \ldots, 2017$

Selanjutnya, dilakukan uji stasioneritas dengan menggunakan uji Augmented Dickey-Fuller (ADF) pada semua variabel dalam penelitian yaitu pertumbuhan transaksi nontunai, pertumbuhan tabungan masyarakat, pertumbuhan jumlah uang beredar (M1), inflasi, dan BI rate.

\section{Membentuk Persamaan Jangka Panjang}

Jika seluruh variabel yang digunakan stasioner pada orde yang sama, dapat diduga bahwa terdapat kointegrasi atau keseimbangan pada persamaan jangka panjang. Persamaan jangka panjang diperoleh dengan meregresikan data yang belum stasioner (data level). Model persamaan jangka panjang yang dibentuk adalah sebagai berikut.

$$
\begin{array}{r}
\text { YOYNONTUNAI }_{t}=\alpha_{0}+\alpha_{1} \text { YOYTABMAS }_{t}+\alpha_{2} \text { YOYM }_{t}+ \\
\alpha_{3} \text { INFLASI }_{t}+\alpha_{4} \text { BIRATE } \\
t+\varepsilon_{t}
\end{array}
$$

Keterangan:

$\mathrm{t}$

$\alpha_{0}$

$\alpha_{i}$

: periode ke-t

: intercept persamaan jangka panjang

$\varepsilon t$

: slope untuk tiap variabel independen ke-i, $i=1,2,3,4$

$\varepsilon_{\mathrm{t}}$

: error persamaan jangka panjang

YOYNONTUNAI

: error persamaan jangka panjang

YOYTABMAS

YOYM1

INFLASI

BIRATE

: pertumbuhan year on year nilai transaksi nontunai

: pertumbuhan year on year tabungan masyarakat

: pertumbuhan year on year jumlah uang beredar

: tingkat inflasi

: $\mathrm{Bl}$ rate

\section{Pengujian kointegrasi}

Pengujian kointegrasi dilakukan untuk mengetahui adanya keseimbangan jangka panjang dari model yang dibentuk. Adanya kointegrasi ditandai dari residual 
persamaan jangka panjang yang stasioner pada level. Jika residual tidak stasioner di level, metode ECM tidak dapat digunakan karena tidak terdapat kointegrasi pada variabel-variabel dalam penelitian. Uji stasioneritas residual yang dihasilkan oleh persamaan jangka panjang ini dilakukan dengan menggunakan uji ADF.

\section{Membentuk Persamaan Jangka Pendek}

Dalam Granger representation theorem, dikatakan bahwa jika dua variabel $Y$ dan $X$ saling terkointegrasi, hubungan antara keduanya dapat dijelaskan dengan ECM (Gujarati, 2004). Metode ECM memasukkan penyesuaian (adjustment) untuk mengoreksi ketidakseimbangan jangka pendek menuju ke keseimbangan jangka panjang. Model ECM dibentuk dengan meregresikan data yang sudah stasioner pada orde yang sama dan menambahkan variabel Error Correction Term (ECT) untuk mendapatkan nilai speed of adjustment. Model persamaan jangka panjang yang diperoleh sebagai berikut:

$\triangle Y O Y N O N T U N A I_{t}=\beta_{0}+\beta_{1} \Delta Y O Y T A B M A S_{t}+\beta_{2} \Delta Y O Y M 1_{t}+$

$$
\beta_{3} \Delta I N F L A S I_{t}+\beta_{4} \Delta B I R A T E_{t}+\beta_{5} E C T_{t-1}+\epsilon_{t}
$$

Keterangan:

$$
\begin{array}{ll}
\Delta & : \text { difference pertama } \\
\beta_{0} & : \text { intercept } \\
\beta_{\mathrm{i}} & : \text { slope untuk tiap variabel independen ke-i, } \mathrm{i}=1,2,3,4 \\
\beta_{5} & : \text { speed of adjustment } \\
\mathrm{ECT}_{\mathrm{t}-1}: \text { Error } & \text { Correction Term } \\
\epsilon_{t} & : \text { error persamaan jangka pendek }
\end{array}
$$

Koefisien ECT dalam persamaan jangka pendek harus negatif dan signifikan dengan nilai lebih kecil dari satu agar ketidakseimbangan jangka pendek dapat disesuaikan menuju keseimbangan jangka panjang. Jika tidak memenuhi syarat tersebut, ECM tidak cocok untuk digunakan.

\section{Uji Keberartian Model}

Pengujian keberartian model dilakukan untuk mengetahui apakah model estimasi yang terbentuk cukup baik dalam menjelaskan data dan koefisien yang dihasilkan sesuai dengan teori atau hipotesis. Beberapa cara untuk mengukur keberartian model antara lain dengan melihat koefisien determinasi $\left(R^{2}\right.$ adj $)$, uji simultan (uji F), dan uji parsial (uji t).

$\mathrm{R}^{2}$ adj menunjukkan berapa persen variabel pertumbuhan tabungan masyarakat, pertumbuhan $\mathrm{M} 1$, inflasi, dan $\mathrm{Bl}$ rate dapat menjelaskan variasi dari variabel pertumbuhan transaksi nontunai. Semakin tinggi $\mathrm{R}^{2}$ adj, semakin besar variasi pertumbuhan transaksi nontunai yang dapat dijelaskan oleh variabel independen.

Selain itu, dilakukan uji signifikansi parameter simultan (uji F) untuk mengetahui pengaruh variabel independen terhadap variabel dependen secara serentak. Setelah dilakukan uji signifikansi parameter secara simultan, dilakukan juga uji signifikansi parameter secara parsial (uji t) untuk mengetahui variabel independen mana saja yang berpengaruh terhadap transaksi nontunai.

\section{Uji Asumsi Klasik}

Model ECM yang digunakan dalam penelitian ini menggunakan estimasi Ordinary Least Square (OLS) sehingga diperlukan uji asumsi klasik agar estimator yang dihasilkan bersifat Best Linear Unbiased Estimator (BLUE). Residual yang dibentuk harus memenuhi asumsi klasik Gauss-Markov yang terdiri dari normalitas, homoskedastisitas, nonautokorelasi, dan nonmultikolinearitas. Pengujian dilakukan pada residual yang didapatkan dari persamaan jangka pendek. 


\section{Hasil dan Pembahasan}

\subsection{Perkembangan Transaksi Nontunai di Indonesia}

Sistem pembayaran nontunai yang pertama kali dikenal masyarakat Indonesia, yaitu cek atau giral yang memungkinkan permbayaran dengan cara transfer dana dari saldo rekening antar institusi keuangan, khususnya bank (Pramono et al., 2006). Akan tetapi, penggunaan cek atau giral ini kurang praktis karena tidak bisa digunakan langsung untuk konsumsi. Seiring dengan perkembangan teknologi, muncul banyak instrumen pembayaran nontunai yang lainnya, seperti kartu kredit, kartu ATM/debit, dan uang elektronik yang merupakan instrumen pembayaran nontunai yang paling sering digunakan masyarakat saat ini. Dengan menggunakan instrumen tersebut, pembayaran nontunai dapat dilakukan melalui transfer antar rekening bank atau menggunakan kartu.
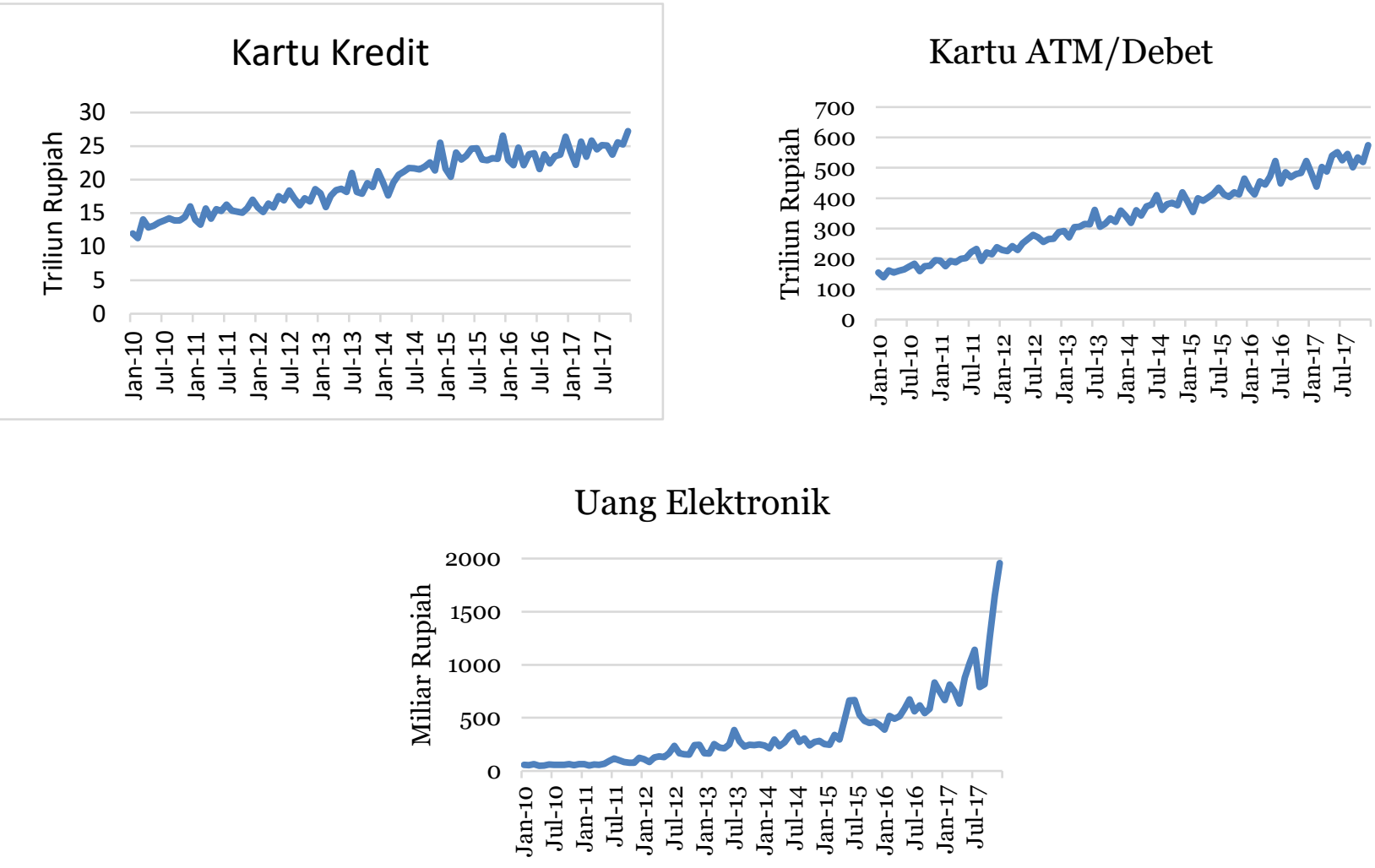

Sumber: Bank Indonesia

Gambar 1: Perkembangan transaksi kartu kredit, ATM/debet, dan uang elektronik di Indonesia 2010-2017

Berdasarkan Gambar 1, perkembangan transaksi kartu kredit di Indonesia pada Januari 2010 hingga Desember 2017 cenderung mengalami peningkatan dengan ratarata transaksi tiap bulan sebesar 19,64 triliun rupiah. Transaksi kartu kredit ini terdiri dari transaksi tunai dan belanja. Nilai transaksi kartu kredit sebesar 11,97 triliun rupiah pada Januari 2010 meningkat menjadi 27,23 triliun rupiah pada Desember 2017. Peningkatan ini disebabkan oleh semakin banyaknya tempat belanja yang menyediakan mesin Electronic Data Capture (EDC) sehingga transaksi menggunakan kartu kredit lebih mudah dilakukan. Akan tetapi, peningkatan transaksi kartu kredit tidak terlalu signifikan karena jumlah kartu kredit yang beredar lebih sedikit dibandingkan kartu ATM/debet. 
Perkembangan transaksi kartu ATM/debet di Indonesia pada Januari 2010 hingga Desember 2017 cenderung mengalami peningkatan dengan rata-rata transaksi tiap bulan sebesar 33,86 triliun rupiah. Transaksi kartu ATM/debet ini terdiri dari transaksi penarikan tunai, belanja, transfer intrabank, dan transfer antarbank. Nilai transaksi kartu ATM/debet sebesar 15,45 triliun rupiah pada Januari 2010 meningkat menjadi 57,45 triliun rupiah pada Desember 2017. Peningkatan ini didukung oleh semakin banyaknya pengguna kartu ATM/debet sehingga banyak dibuat infrastruktur pendukung seperti mesin ATM, mobile banking, dan internet banking.

Perkembangan transaksi uang elektronik pada Januari 2010 hingga Desember 2017 cenderung mengalami peningkatan dengan rata-rata transaksi tiap bulan sebesar 360,37 miliar rupiah. Jika dibandingkan dengan transaksi kartu kredit dan kartu ATM/debet, transaksi uang elektronik menunjukkan peningkatan yang paling signifikan. Transaksi uang elektronik yang hanya sebesar 57,41 miliar rupiah pada Januari 2010 meningkat menjadi 1957,29 miliar rupiah pada Desember 2017. Meskipun pada awalnya peningkatan transaksi uang elektronik hanya sedikit, setelah adanya GNNT transaksi uang elektronik meningkat secara signifikan, terlebih pada periode September hingga Desember 2017. Hal ini didukung oleh banyaknya penggunaan uang elektronik dalam kegiatan sehari-hari seperti untuk transportasi menggunakan TransJakarta, kereta commuter line, dan e-Toll.

\subsection{Perkembangan Tabungan Masyarakat di Indonesia}

Tabungan masyarakat merupakan variabel penting dalam pertumbuhan ekonomi karena bisa dijadikan sumber modal yang efektif bagi kegiatan investasi dan melakukan pembangunan secara mandiri. Oleh karena itu, pemerintah terus berupaya untuk meningkatkan kesadaran masyarakat Indonesia untuk menabung sehingga tabungan masyarakat dapat meningkat.

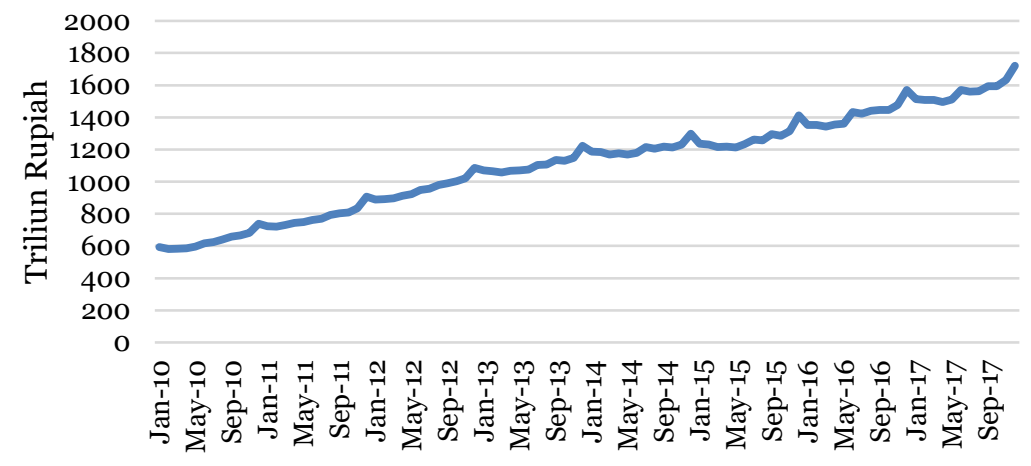

Sumber: Bank Indonesia

Gambar 2: Perkembangan tabungan masyarakat Indonesia 2010-2017.

Berdasarkan Gambar 2, perkembangan jumlah tabungan masyarakat Indonesia pada Januari 2010 hingga Desember 2017 cenderung meningkat dengan rata-rata pertumbuhan 13,98 persen tiap tahunnya. Jumlah tabungan masyarakat pada Januari 2010 sebesar 593,9 triliun rupiah dan meningkat menjadi 1721 triliun rupiah pada Desember 2017. Peningkatan jumlah tabungan masyarakat yang dihimpun oleh perbankan ini menunjukkan bahwa semakin banyak masyarakat sadar akan pentingnya menabung dan menyimpan dananya di bank.

Meskipun jumlah tabungan masyarakat Indonesia memiliki kecenderungan naik, pertumbuhan tabungan masyarakat pada Januari 2010 hingga Desember 2017 cukup 
berfluktuasi. Pertumbuhan yang terus meningkat terjadi pada 2010 hingga 2012 dengan pertumbuhan tertinggi sebesar 26,66 persen pada April 2011. Mulai pertengahan 2012 hingga pertengahan 2015, pertumbuhan tabungan masyarakat Indonesia cenderung mengalami perlambatan. Salah satu penyebabnya adalah kondisi ekonomi global yang melemah dan memengaruhi kondisi perekonomian Indonesia. Selanjutnya, pertumbuhan tabungan masyarakat Indonesia mengalami peningkatan hingga Juni 2016, tetapi kembali melambat hingga akhir 2017.

\subsection{Perkembangan Jumlah Uang Beredar di Indonesia}

Jumlah uang beredar dapat mencerminkan permintaan uang di masyarakat dan merupakan variabel yang penting dalam penentuan kebijakan moneter. Jumlah uang beredar dalam arti sempit (M1) menunjukkan jumlah uang kartal dan giral yang beredar di masyarakat.

Secara umum, berdasarkan Gambar 3, perkembangan jumlah M1 yang beredar pada Januari 2010 hingga Desember 2017 cenderung meningkat dengan rata-rata pertumbuhan 13,31 persen tiap tahunnya. Pada Januari 2010, jumlah M1 yang beredar sebanyak 496,5 triliun rupiah dan menjadi 1390,8 triliun rupiah pada Desember 2017. Jumlah uang beredar yang terus meningkat ini umumnya didorong oleh tingginya permintaan uang kartal menjelang lebaran, awal tahun pendidikan, serta natal dan libur akhir tahun.

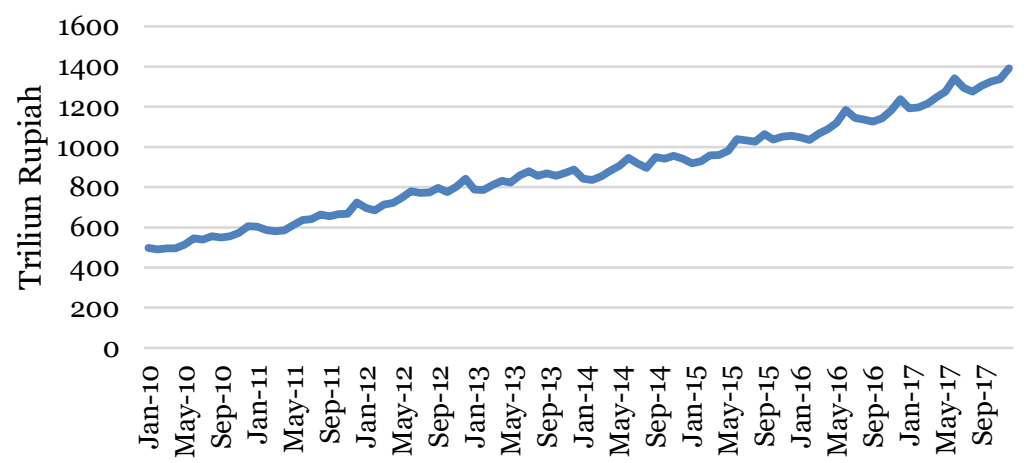

Sumber: Bank Indonesia

Gambar 3: Perkembangan jumlah uang beredar (M1) di Indonesia 2010-2017

Perkembangan M1 yang cenderung meningkat ini tidak selalu diiringi oleh peningkatan pertumbuhannya. Pertumbuhan M1 pada Mei 2012 hingga Juli 2014 cenderung mengalami perlambatan. Hal ini dipicu oleh melambatnya pertumbuhan giro rupiah. Pada periode selanjutnya, yaitu Agustus 2014 hingga Desember 2017, pertumbuhan M1 cenderung mengalami peningkatan meskipun fluktuatif. Perlambatan pertumbuhan terbesar terjadi pada September 2016 yang didorong oleh melambatnya pertumbuhan uang kartal pada pada periode tersebut jika dibandingkan dengan periode tahun sebelumnya.

\subsection{Perkembangan Inflasi di Indonesia}

Inflasi merupakan salah satu indikator moneter yang sangat diperhatikan oleh pemerintah karena keberhasilan kebijakan moneter tercermin dari keberhasilan dalam mengendalikan inflasi. Perkembangan inflasi di Indonesia sejak Januari 2010 hingga Desember 2017 ditunjukkan pada Gambar 4. 


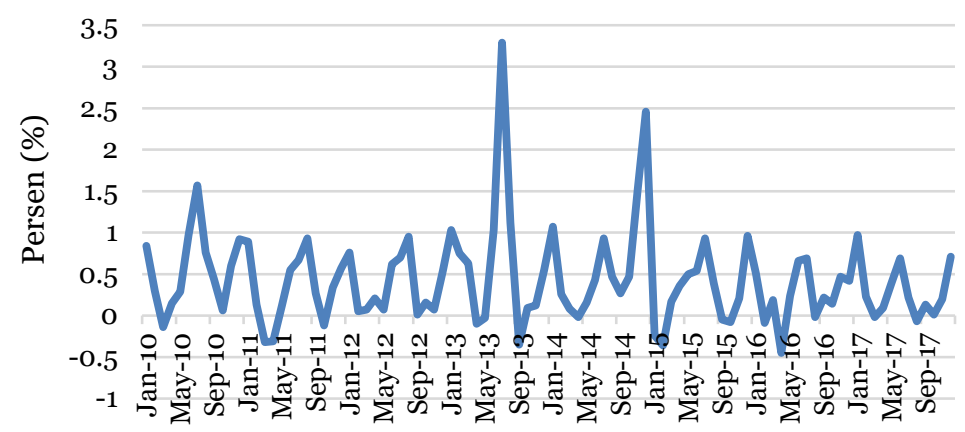

Sumber: Badan Pusat Statistik

Gambar 4: Perkembangan inflasi di Indonesia 2010-2017

Secara umum, tingkat inflasi di Indonesia cenderung berfluktuatif dengan tingkat inflasi yang rendah. Tingkat inflasi yang tinggi berada di sekitar bulan Januari dan Juli pada setiap tahunnya. Hal ini terjadi karena adanya libur sekolah dan libur akhir tahun yang membuat masyarakat cenderung meningkatkan konsumsinya sehingga permintaan barang dan jasa melebihi persediaannya. Akibatnya, harga barang dan jasa naik sehingga memicu inflasi.

Berdasarkan Gambar 4, inflasi yang melonjak pada Juli 2013 sebesar 3,29 persen disebabkan oleh naiknya harga Bahan Bakar Minyak (BBM) sehingga terjadi kenaikan harga barang dan jasa. Hal yang sama terjadi pada Desember 2014, inflasi sebesar 2,46 persen disebabkan oleh keputusan pemerintah untuk menaikkan harga BBM. Deflasi pada Maret 2010 dan 2011 sebesar 0,14 dan 0,32 persen disebabkan oleh turunnya harga bahan pokok seperti cabai dan beras. Demikian juga dengan deflasi pada September 2013 sebesar 0,35 persen yang dipicu oleh turunnya beberapa harga komoditas seperti bawang merah, cabai rawit, sawi hijau, dan telur. Deflasi tertinggi terjadi pada April 2016, yaitu sebesar 0,45 persen yang disebabkan oleh turunnya harga barang dan jasa yang dipicu oleh keputusan pemerintah untuk menurunkan harga BBM.

\subsection{Perkembangan BI Rate di Indonesia}

$\mathrm{BI}$ rate digunakan sebagai acuan dalam menetapkan nilai suku bunga seluruh bank di Indonesia. Pada periode sebelum Juli 2005, suku bunga acuan tidak menggunakan BI rate melainkan menggunakan suku bunga SBI (Surat Bank Indonesia). Selanjutnya pada Agustus 2016, Bank Indonesia merilis suku bunga acuan baru yang disebut BI-7 Days Repo Rate. Suku bunga acuan menjadi kebijakan moneter yang ditetapkan oleh Bank Indonesia sebagai respons dari naik atau turunnya inflasi.

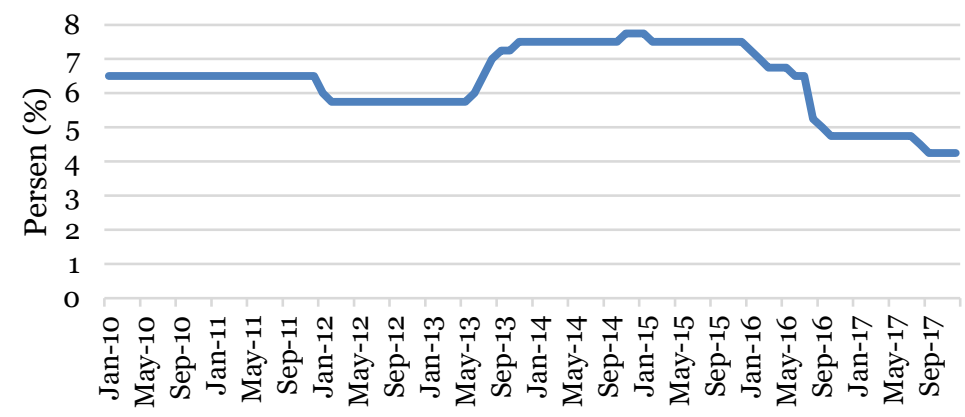

Sumber: Bank Indonesia

Gambar 5: Perkembangan BI rate di Indonesia 2010-2017 
Berdasarkan Gambar 5, pergerakan BI rate tiap bulannya cenderung konstan dan berkisar pada empat hingga delapan persen. Pada periode Januari 2010 hingga Desember 2011, BI rate konstan dengan nilai sebesar 6,5 persen. Selanjutnya, pada Januari 2012 nilai BI rate mulai turun dan konstan di 5,75 persen mulai Februari 2012 hingga Mei 2013. Nilai BI rate yang tinggi pada pertengahan 2013 hingga awal 2016 dipicu oleh tingginya tingkat inflasi. Sejak Agustus 2013 hingga Februari 2016, nilai BI rate berkisar di angka tujuh persen dengan nilai tertinggi sebesar 7,75 persen pada Desember 2014 dan Januari 2015. Hal ini disebabkan oleh naiknya harga BBM yang memicu inflasi sehingga BI rate juga dinaikkan. Selain itu, kenaikan BI rate juga dipicu oleh adanya pelemahan ekonomi global yang menyebabkan melemahnya sektor keuangan. Sejak Maret 2016, nilai BI rate terus menurun hingga mencapai nilai terendah sebesar 4,25 persen pada September hingga Desember 2017. Turunnya nilai $\mathrm{BI}$ rate juga dipicu oleh tingkat inflasi yang rendah dan stabil di bawah satu persen.

\subsection{Pengaruh Tabungan Masyarakat, Jumlah Uang Beredar (M1), Inflasi, dan BI Rate terhadap Transaksi Nontunai}

\section{Uji Stasioneritas}

Pengujian stasioneritas dilakukan menggunakan uji ADF pada semua variabel penelitian. Uji stasioneritas dilakukan pada data level dan first difference untuk mengetahui apakah variabel memiliki akar unit atau tidak. Ringkasan hasil uji stasioneritas data menggunakan ADF adalah sebagai berikut:

Tabel 1. Hasil uji akar unit pada variabel penelitian

\begin{tabular}{|c|c|c|c|}
\hline \multirow{2}{*}{ Variabel } & \multicolumn{2}{|c|}{$p$-value } & \multirow{2}{*}{ Kesimpulan } \\
\hline & Level & First Difference & \\
\hline (1) & (2) & (3) & (4) \\
\hline YOYNONTUNAI & 0,0104 & 0,0000 & Stasioner pada I(0) \\
\hline YOYTABMAS & 0,1842 & 0,0000 & Stasioner pada I(1) \\
\hline YOYM1 & 0,0502 & 0,0000 & Stasioner pada I(1) \\
\hline INFLASI & 0,0000 & 0,0000 & Stasioner pada I (0) \\
\hline BIRATE & 0,3187 & 0,0000 & Stasioner pada I(1) \\
\hline
\end{tabular}

Berdasarkan hasil pada Tabel 1, diperoleh hasil bahwa variabel pertumbuhan transaksi nontunai dan inflasi sudah stasioner di level, sedangkan variabel pertumbuhan tabungan masyarakat, pertumbuhan $\mathrm{M} 1$, dan $\mathrm{BI}$ rate stasioner di first difference. Menurut Lee dan Granger dalam Enders (2014), saat variabel stasioner pada derajat integrasi yang berbeda, variabel-variabel tersebut tetap dapat memiliki kointegrasi. Beberapa variabel ekonomi biasanya sudah stasioner di level sehingga derajat integrasinya dapat dinaikkan untuk menyetarakan variabel-variabel lain yang stasioner di derajat integrasi berbeda. Oleh sebab itu, dengan tingkat signifikansi lima persen dapat disimpulkan bahwa variabel-variabel dalam penelitian stasioner pada orde yang sama, yaitu orde satu $(I(1))$. Hal ini menyatakan bahwa pemodelan menggunakan ECM dapat dilanjutkan karena sudah memenuhi syarat awal pemodelan ECM.

\section{Pembentukan Persamaan Jangka Panjang (Pengujian Kointegrasi)}

Setelah melakukan uji stasioneritas, proses selanjutnya adalah melakukan pengujian kointegrasi dengan cara menguji stasioneritas dari residual yang dihasilkan oleh persamaan jangka panjang. Persamaan jangka panjang yang dibentuk dari variabel-variabel pada level adalah sebagai berikut: 


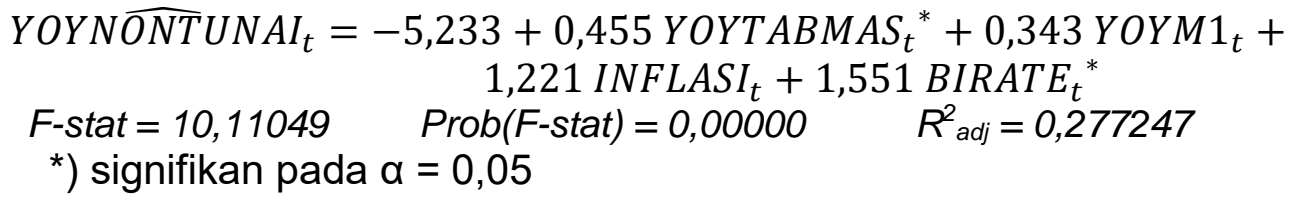

Nilai Prob(F-Stat) yang dihasilkan persamaan jangka panjang sebesar 0,00000 atau lebih kecil dari 0,05 berarti hipotesis nol ditolak sehingga dengan tingkat signifikansi sebesar lima persen dapat disimpulkan bahwa minimal ada satu variabel independen yang memengaruhi pertumbuhan transaksi nontunai. Nilai $R^{2}$ adj yang dihasilkan sebesar 0,277247 yang berarti 27,72 persen variasi pertumbuhan transaksi nontunai dapat dijelaskan oleh pertumbuhan tabungan masyarakat, pertumbuhan M1, inflasi, dan $\mathrm{BI}$ rate, sedangkan 72,28 persen variasi pertumbuhan transaksi nontunai dijelaskan oleh variabel lain di luar persamaan. Selain itu, dilakukan uji parsial untuk mengetahui pengaruh masing-masing variabel independen terhadap variabel dependen. Dengan tingkat signifikansi sebesar lima persen, dapat disimpulkan bahwa variabel yang memengaruhi transaksi nontunai pada jangka panjang adalah tabungan masyarakat dan $\mathrm{BI}$ rate, sedangkan variabel M1 dan inflasi tidak memengaruhi transaksi nontunai.

Sebelum membentuk persamaan jangka pendek, uji kointegrasi harus dilakukan untuk melihat hubungan jangka panjang antara variabel-variabel yang digunakan. Dari persamaan (3), diperoleh nilai residual untuk diuji stasioneritasnya pada tingkat level. Dengan menggunakan uji ADF, diperoleh nilai $p$-value sebesar 0,0001 yang lebih kecil dari tingkat signifikansi sebesar lima persen sehingga dapat disimpulkan bahwa residual sudah stasioner di level. Hal ini menunjukkan bahwa variabel-variabel yang digunakan dalam penelitian ini saling terkointegrasi atau memiliki hubungan keseimbangan jangka panjang.

\section{Persamaan Error Correction Mechanism (ECM)}

Pembentukan model ECM digunakan untuk menjelaskan bagaimana pengaruh pertumbuhan tabungan masyarakat, pertumbuhan $\mathrm{M} 1$, inflasi, dan $\mathrm{BI}$ rate terhadap pertumbuhan transaksi nontunai pada jangka pendek. Estimasi dilakukan dengan menggunakan hasil uji kointegrasi yang sudah diperoleh dan variabel-variabel yang sudah stasioner (data first difference). Persamaan jangka pendek yang dibentuk adalah sebagai berikut:

$$
\begin{aligned}
& \triangle Y O Y \text { ONTUNAI } I_{t}=0,23+1,182 \triangle Y O Y T A B M A S_{t}{ }^{*}+0,701 \triangle Y O Y M 1_{t}{ }^{*}+ \\
& 0,791 \Delta \text { INFLASI }_{t}-0,967 \Delta \text { BIRATE }_{t}-0,551 E \text { CT }_{t-1}{ }^{*} \\
& \text { F-stat }=14,56945 \operatorname{Prob}(F \text {-stat })=0,00000 \quad R^{2}{ }_{a d j}=0,419205 \\
& \text { *) signifikan pada } \alpha=0,05
\end{aligned}
$$

Persamaan jangka pendek yang ditunjukkan oleh persamaan (5) menghasilkan nilai $F$-stat sebesar 14,56945 dengan Prob(F-stat) sebesar 0,00000. Nilai Prob(F-stat) yang lebih kecil dari tingkat signifikansi sebesar lima persen menunjukkan bahwa minimal ada satu variabel independen yang memengaruhi perubahan pertumbuhan transaksi nontunai. Nilai $\mathbf{R}^{2}$ adj yang dihasilkan sebesar 0,419205 menunjukkan bahwa 41,92 persen variasi dari perubahan pertumbuhan transaksi nontunai dapat dijelaskan oleh variabel-variabel independen dalam model, sedangkan 58,08 persen sisanya dijelaskan oleh variabel lain yang tidak ada dalam model.

Koefisien Error Correcting Term (ECT) dalam model ECM menunjukkan besarnya elemen penyesuaian (speed of adjustment) terhadap persamaan jangka panjang. Nilai koefisien ECT harus negatif dan signifikan yang menunjukkan adanya penurunan ke arah keseimbangan. Koefisien ECT yang dihasilkan persamaan (5) bernilai -0,551 
dengan $p$-value sebesar 0,0000 yang berarti nilainya signifikan. Hal ini berarti fluktuasi keseimbangan jangka pendek akan dikoreksi menuju ke keseimbangan jangka panjang, dimana sekitar 55,1 persen proses koreksinya terjadi pada bulan pertama dan 44,9 persen proses koreksinya terjadi pada bulan-bulan selanjutnya.

Secara parsial, tidak semua variabel independen yang ada pada persamaan jangka pendek memiliki pengaruh terhadap perubahan pertumbuhan transaksi nontunai. Variabel independen yang berpengaruh terhadap perubahan pertumbuhan transaksi nontunai pada jangka pendek dengan tingkat signifikansi lima persen adalah variabel perubahan pertumbuhan tabungan masyarakat dan perubahan pertumbuhan M1. Variabel perubahan inflasi dan $\mathrm{BI}$ rate tidak berpengaruh terhadap perubahan pertumbuhan transaksi nontunai.

Dalam jangka pendek maupun jangka panjang, variabel pertumbuhan tabungan masyarakat berpengaruh positif pada tingkat signifikansi lima persen terhadap pertumbuhan transaksi nontunai di Indonesia. Nilai koefisien perubahan pertumbuhan tabungan masyarakat yang dihasilkan pada jangka pendek sebesar 1,182 yang berarti setiap peningkatan dari perubahan pertumbuhan tabungan masyarakat sebesar satu persen, akan meningkatkan perubahan pertumbuhan transaksi nontunai sebesar 1,182 persen dengan asumsi variabel lain bersifat konstan.

Berdasarkan teori konsumsi Keynes, peningkatan pendapatan seseorang akan diikuti peningkatan tingkat konsumsinya. Dalam hal ini, tabungan menjadi sumber dana untuk melakukan konsumsi atau dengan kata lain tabungan dapat diibaratkan menjadi pendapatan. Tabungan yang digunakan bukan hanya berasal dari selisih pendapatan dan konsumsi, tetapi juga akumulasi dari tabungan di periode sebelumnya. Hal ini menjadikan adanya hubungan positif antara tabungan dan konsumsi sehingga semakin tinggi tabungan juga akan meningkatkan konsumsi. Peningkatan konsumsi ini tentu akan berdampak terhadap transaksi nontunai karena masyarakat juga melakukan pembayaran dengan nontunai. Selain itu, dana yang ada di rekening tabungan juga dapat digunakan untuk bertransaksi nontunai sehingga semakin banyak dana yang ada di tabungan, semakin banyak pula transaksi nontunai yang dapat dilakukan.

Dalam jangka pendek, variabel perubahan pertumbuhan $\mathrm{M} 1$ berpengaruh positif pada tingkat signifikansi lima persen terhadap perubahan pertumbuhan transaksi nontunai di Indonesia. Nilai koefisien yang dihasilkan sebesar 0,701 yang berarti setiap peningkatan dari perubahan pertumbuhan $M 1$ sebesar satu persen, akan meningkatkan perubahan pertumbuhan transaksi nontunai sebesar 0,701 persen dengan asumsi variabel lain bersifat konstan. Namun, pada jangka panjang pertumbuhan $\mathrm{M} 1$ tidak berpengaruh terhadap pertumbuhan transaksi nontunai di Indonesia dengan koefisien yang dihasilkan bertanda positif.

Hubungan positif antara M1 dan transaksi nontunai ini sesuai dengan penelitian Astuti (2017) yang menyatakan bahwa jumlah uang beredar berpengaruh positif terhadap permintaan uang elektronik di Indonesia. Hal ini menunjukkan bahwa M1 dan transaksi nontunai memiliki hubungan komplementer atau melengkapi satu sama lain. Bank Indonesia juga menjelaskan bahwa transaksi tunai dan nontunai bukan berperan sebagai substitusi melainkan sebagai pelengkap dalam sistem pembayaran di Indonesia. Masyarakat Indonesia sudah terbiasa dengan dual economy, termasuk dalam hal bertransaksi. Banyaknya transaksi tunai menunjukkan bahwa masyarakat tetap menyukai uang yang memiliki bentuk fisik walaupun sering melakukan transaksi nontunai sehingga peningkatan jumlah uang beredar juga diiringi peningkatan transaksi nontunai. 
Variabel inflasi tidak berpengaruh terhadap pertumbuhan transaksi nontunai di Indonesia pada tingkat signifikansi lima persen, baik pada jangka pendek maupun jangka panjang. Koefisien yang didapat pada persamaan jangka pendek dan jangka panjang bertanda positif yang berarti masyarakat akan tetap melakukan transaksi nontunai untuk melakukan konsumsi meskipun inflasi terjadi. Kegiatan konsumsi di masyarakat tidak terganggu karena inflasi masih rendah dan masyarakat tetap berusaha untuk memenuhi kebutuhan hidupnya walaupun harus membayar lebih mahal karena adanya kenaikan harga sehingga inflasi dan transaksi nontunai berhubungan positif.

Peningkatan transaksi nontunai akibat inflasi ini dapat mendorong perekonomian karena berhubungan dengan konsumsi masyarakat. Dalam penelitiannya, Nur (2012) mengatakan bahwa inflasi memiliki dampak positif dan dampak negatif tergantung parah tidaknya inflasi. Tingkat inflasi Indonesia yang cenderung rendah dan stabil memberikan dampak positif bagi perekonomian yang ditunjukkan dari hubungan positif antara inflasi dan transaksi nontunai.

$\mathrm{BI}$ rate tidak berpengaruh terhadap pertumbuhan transaksi nontunai pada jangka pendek dengan koefisien yang dihasilkan bertanda negatif, tetapi memiliki pengaruh positif pada jangka panjang dengan tingkat signifikansi lima persen. Hubungan negatif di jangka pendek berarti nilai $\mathrm{BI}$ rate yang tinggi akan mengurangi transaksi nontunai yang dilakukan masyarakat karena mereka lebih memilih untuk menyimpan uangnya di bank agar mendapat bunga yang tinggi. Namun, hasil yang tidak signifikan menunjukkan bahwa masyarakat tetap melakukan transaksi nontunai meskipun terjadi perubahan pada $\mathrm{BI}$ rate. Nilai $\mathrm{BI}$ rate yang cenderung konstan pada waktu yang cukup lama membuat masyarakat lebih memilih menggunakan uangnya untuk melakukan konsumsi dengan bertransaksi nontunai dibandingkan untuk ditabung.

Hubungan positif pada jangka panjang berarti peningkatan $\mathrm{BI}$ rate akan diikuti oleh peningkatan transaksi nontunai. Dalam jangka panjang, sebagian pendapatan yang diterima akan ditabung, selain sebagai motif berjaga-jaga juga untuk mendapatkan bunga yang tinggi. Tabungan ini nantinya digunakan sebagai sumber dana untuk melakukan konsumsi. Penelitian yang dilakukan Meilani (2012) memperoleh hasil bahwa suku bunga berpengaruh positif terhadap pengeluaran konsumsi masyarakat. Tingginya suku bunga yang meningkatkan konsumsi ini selanjutnya akan meningkatkan transaksi nontunai yang dilakukan masyarakat. Selain itu, suku bunga yang dianggap sebagai opportunity cost dalam memegang uang juga akan berpengaruh terhadap transaksi nontunai. Semakin tinggi biaya yang dikeluarkan untuk memegang uang tunai, semakin banyak orang yang beralih ke transaksi nontunai agar biaya yang dikeluarkan lebih rendah.

\section{Pengujian Asumsi Klasik}

Model jangka pendek yang dibentuk melalui model ECM harus memenuhi asumsi klasik untuk mendapatkan estimator yang bersifat BLUE (Best Linear Unbiased Estimator). Asumsi klasik yang harus dipenuhi adalah asumsi normalitas, homoskedastisitas, nonautokorelasi, dan nonmultikolinearitas.

Pengecekan asumsi normalitas dilakukan menggunakan uji Jarque-Bera (JB) dengan hipotesis nol error berdistribusi normal. Nilai probabilitas uji JB yang didapatkan sebesar 0,174621 yang lebih besar dari tingkat signifikansi lima persen sehingga gagal tolak $\mathrm{HO}$. Hal ini menunjukkan bahwa residual berdistribusi normal atau asumsi normalitas terpenuhi.

Untuk mendeteksi homoskedastisitas dengan hipotesis nol yang diajukan adalah varian error konstan, dilakukan uji Breusch-Pagan-Godfrey. Nilai probabilitas chisquare yang didapatkan dalam uji ini adalah sebesar 0,2871 . Nilai ini lebih besar dari 
tingkat signifikansi yang digunakan, yaitu lima persen sehingga dapat disimpulkan bahwa varian dari residual konstan atau asumsi homoskedastisitas terpenuhi.

Asumsi nonautokorelasi terpenuhi saat tidak terdapat korelasi antar error, yang dijadikan hipotesis nol dalam pengujian asumsi nonautokorelasi. Pengujian dilakukan menggunakan Breusch-Godfrey Serial Correlation LM Test. Nilai probabilitas chisquare yang didapatkan dalam uji ini adalah sebesar 0,1645 yang lebih besar dari tingkat signifikansi yang digunakan, yaitu lima persen. Hal ini menunjukkan bahwa tidak terdapat korelasi antar residual sehingga asumsi nonautokorelasi terpenuhi.

Multikolinearitas terjadi saat variabel-variabel independen yang digunakan dalam model saling berkorelasi. Pengecekan multikolinearitas dilakukan dengan melihat nilai Variance Inflation Factors (VIF) yang dihasilkan masing-masing variabel independen dalam penelitian. Asumsi nonmultikolinearitas terlanggar apabila nilai VIF dari variabel independen lebih besar dari sepuluh. Nilai VIF yang dihasilkan semua variabel independen pada penelitian ini berkisar pada angka satu yang berarti bernilai kurang dari lima sehingga asumsi nonmultikolinearitas terpenuhi.

Berdasarkan uraian di atas, dapat disimpulkan bahwa model persamaan jangka pendek yang dibentuk sudah memenuhi asumsi klasik berupa asumsi normalitas, homoskedastisitas, nonautokorelasi, dan nonmultikolinearitas. Dengan terpenuhinya asumsi-asumsi tersebut, estimator yang dihasilkan dapat dikatakan memiliki sifat BLUE sehingga dapat digunakan untuk mengestimasi pengaruh tabungan masyarakat, M1, inflasi, dan BI rate terhadap transaksi nontunai di Indonesia.

\section{Simpulan}

Berdasarkan hasil dan pembahasan yang telah dilakukan, kesimpulan dari penelitian ini adalah sebagai berikut.

Pertama, pada periode Januari 2010 hingga Desember 2017, perkembangan transaksi kartu kredit, kartu ATM/debit, uang elektronik, tabungan masyarakat, dan jumlah uang beredar (M1) di Indonesia memiliki kecenderungan naik, sedangkan perkembangan inflasi dan $\mathrm{BI}$ rate Indonesia berfluktuasi dari waktu ke waktu.

Kedua, pada jangka panjang, pertumbuhan tabungan masyarakat dan BI rate berpengaruh positif terhadap pertumbuhan transaksi nontunai di Indonesia, sedangkan pertumbuhan jumlah uang beredar (M1) dan inflasi tidak berpengaruh terhadap pertumbuhan transaksi nontunai di Indonesia.

Ketiga, pada jangka pendek, pertumbuhan tabungan masyarakat dan pertumbuhan jumlah uang beredar (M1) berpengaruh positif terhadap pertumbuhan transaksi nontunai di Indonesia, sedangkan inflasi dan $\mathrm{BI}$ rate tidak berpengaruh terhadap transaksi nontunai. 


\section{Daftar Pustaka}

Astuti, R. D. (2017). Analisis Pengaruh Jumlah Uang Beredar, Pendapatan Perkapita, dan Kecepatan Perputaran Uang Terhadap Permintaan Uang Elektronik di Indonesia [Skripsi], Yogyakarta: Universitas Muhammadiyah Yogyakarta.

Guariglia, A., \& Loke, Y. J. (2004). What Determines The Value and Volume of Noncash Transactions? Evidence from a Panel of European and North American Countries, Applied economics, 36(4), 291-303.

Embu, W. S. (2017). "BPS Akui Indonesia Belum Punya Data Lengkap Jumlah ECommerce". 8 Agustus 2018. url: https://m.merdeka.com/uang/bps-akui-indonesiabelum-punya-data-lengkap-jumlah-e-commerce.html.

Enders, W. (2014). Applied Econometric Time Series, 4th Edition. John Wiley \& Sons.

Gujarati, D. (2004). Basic Econometrics (4thedition), New York: Mc Graw Hill.

Marta, M. F. (2017). “Daya Beli Turun atau Orang Malas Belanja?". 11 November 2017. url: http://ekonomi.kompas.com/read/2017/09/20/060000026/daya-beli-turun-atauorang-malas-belanja-.

Meilani, D. N. (2016). Analisis Faktor-Faktor yang Mempengaruhi Pengeluaran Konsumsi Masyarakat di Indonesia Tahun 1995-2014 [Skripsi], Yogyakarta: Universitas Islam Indonesia.

Persaulian, B., Aimon, H., \& Anis, A. (2013). Analisis Konsumsi Masyarakat di Indonesia, Jurnal Kajian Ekonomi, 1(2).

Pramono, B., Yanuarti, T., Purusitawati, P. D., \& Emmy, Y. T. (2006). Dampak Pembayaran Non Tunai Terhadap Perekonomian dan Kebijakan Moneter, Working Paper Nomor 11, Jakarta: Bank Indonesia.

Putera, D. E. K. (2017). Peran Uang Elektronik dalam Laju Inflasi di Indonesia Tahun 2010-2016, Jurnal Ilmiah Mahasiswa FEB, 5(2).

Ragandhi, A. (2011). Pengaruh Pendapatan Nasional, Inflasi dan Suku Bunga Deposito Terhadap Konsumsi Masyarakat di Indonesia [Disertasi], Surakarta: Universitas Sebelas Maret.

Widarjono, A. (2005). Ekonometrika: Teori dan Aplikasi untuk Ekonomi dan Bisnis, Yogyakarta: Ekonisia. 